\title{
Radioiodine therapy accelerates apoptosis in peripheral blood lymphocytes of patients with differentiated thyroid cancer
}

\author{
O. VRNDIC ${ }^{1}$, O. MILOSEVIC-DJORDJEVIC ${ }^{1,2}$, P. DJURDJEVIC ${ }^{1,3}$, D. JOVANOVIC ${ }^{1,3}$, L. MIJATOVIC ${ }^{1,3}$, I. JEFTIC ${ }^{1}$, S. ZIVANCEVIC SIMONOVIC ${ }^{1, *}$ \\ ${ }^{1}$ Faculty of Medical Sciences, University of Kragujevac, Kragujevac, Serbia; ${ }^{2}$ Faculty of Science, University of Kragujevac, Kragujevac, Serbia; \\ ${ }^{3}$ Clinical Center Kragujevac, Kragujevac, Serbia
}

${ }^{*}$ Correspondence: simonov@eunet.rs

Received December 23, 2012/ Accepted February 13, 2013

\begin{abstract}
Both apoptosis and micronuclei formation reflect cytogenetic damage in cells and could contribute to cell homeostasis. The aim of this study was to evaluate apoptosis in peripheral blood lymphocytes (PBLs) of patients with differentiated thyroid cancer (DTC) before and after 131-iodine (131-I)-therapy and its correlation with micronuclei (MN) frequency. The study population included 18 DTC patients and 18 healthy donors. Apoptotic cells were detected using the Annexin V-FITC/7-AAD kit and MN frequency by cytokinesis-block MN assay. The difference between early apoptosis in PBLs of DTC patients before therapy and controls $(9.88 \pm 4.99 \%$ vs. $6.64 \pm 2.07 \%, \mathrm{p}=0.003)$ was significant, as well as between early apoptosis in PBLs of DTC patients before and after 131-I-therapy ( $9.88 \pm 4.99 \%$ vs. $13.53 \pm 6.57 \%, \mathrm{p}=0.008)$. The $\mathrm{MN}$ frequency and early apoptosis in PBLs of DTC patients was positively correlated before $(\mathrm{r}=0.540, \mathrm{p}=0.021)$ and after 131-I-therapy $(\mathrm{r}=0.585, \mathrm{p}=0.014)$. Thyroid cancer patients had a significantly increased early apoptosis in PBLs, which further increased after 131-I-therapy in association with MN frequency.
\end{abstract}

Key words: apoptosis, differentiated thyroid cancer, micronuclei, peripheral blood lymphocytes, radioactive iodine

Apoptosis is a physiological process involving many morphological and biochemical changes whereby most cells are eliminated. The typical morphological changes are shrinkage of the cell, fragmentation into membrane-bound apoptotic bodies and rapid phagocytosis by neighboring cells [1,2]. During the process of apoptosis, the appearance of phosphatidylserine on the outer leaflet of the cell membrane occurs relatively early in cells in which the integrity of the cell membrane is maintained and facilitates non-inflammatory phagocytic recognition of apoptotic cells $[3,4]$. In the late stage of apoptosis, the integrity of the cell membrane is lost $[4,5]$.

Deregulation of apoptosis may be of primary importance in the pathogenesis of many diseases [6]. Spontaneous ex vivo apoptosis of circulating peripheral blood lymphocytes (PBLs) has been evaluated in patients with head and neck carcinoma [7], carcinoma of the digestive tract [8] and reproductive system [9, 10], breast carcinoma [11], melanoma [12] and multiple myeloma [13]. Therapy applied to patients with different types of tumors may accelerate apoptosis of malignant cells, so increase in apoptosis might be a suitable target for therapy $[14,15,16]$.
Micronuclei $(\mathrm{MN})$ are chromosomal fragments or whole chromosomes that are not included in the nuclei during division. They appear in the cytoplasm of daughter cells as small additional nuclei [17]. PBLs of cancer patients have a higher micronuclei $(\mathrm{MN})$ frequency than those of healthy persons $[18,19,20]$, which additionally increased after therapy $[21,22]$. Both apoptosis and micronuclei formation reflect cytogenetic damage in cells and could contribute to cell homeostasis.

The MN frequency in PBLs of patients with differentiated thyroid cancers (DTCs) before and after 131-I therapy has already been studied [23, 24, 25], but the level of apoptosis in PBLs of patients with DTC treated with 131-I has not been investigated so far. The aim of our study was to determine the level of apoptosis of PBLs in thyroid cancer patients before and after 131-I therapy, and to correlate its intensity with $\mathrm{MN}$ frequency.

\section{Patients and methods}

Study population. The study was approved by the Ethical Committee of the Clinical Center Kragujevac. All patients and 
control subjects gave written informed consent according to the Helsinki Declaration.

The study population included 18 well-DTC patients of mean age $50.5 \pm 11.5$ years. Following surgical thyroidectomy, the patients were treated at the Nuclear Medicine Department of the Clinical Center Kragujevac according to EANM guidelines [26] with fixed nominal activities of $3.7 \mathrm{GBq}(100$ $\mathrm{mCi})$ (11 patients) or $5.5 \mathrm{GBq}(150 \mathrm{mCi})(7$ patients) of sodium [131-I]iodide administered orally. At the time of 131-I administration, all patients were hypothyroid after thyroid hormone withdrawal (TSH $>30 \mathrm{mIU} / \mathrm{L}$ ). The control group was composed of 18 healthy subjects of mean age $46.7 \pm 13.9$ years. They were colleagues and relatives willing to participate, who had not been exposed to radioactive sources or other known genotoxic agents for a minimum of 3 months before. Blood samples from control subjects were taken only once, while blood samples from DTC patients were obtained twice: before and 7 days after 131-I treatment.

None of the patients had been exposed to potentially confounding factors, such as other ionizing radiations (radiographic examination or scintigraphy) within 3 months before therapy. Patients were released from hospital 3 days after 131-I therapy or later, when measured residual activity had reached a value below $2 \mathrm{mR} / \mathrm{h}$.

Isolation of peripheral blood mononuclear cells. Blood samples were collected in the morning in polystyrene tubes. Heparinized peripheral blood $(10 \mathrm{ml})$ was centrifuged at $400 \mathrm{xg}$ for $10 \mathrm{~min}$ to separate plasma and cells. Peripheral blood mononuclear and polymorphonuclear cells were separated by single step continuous density-gradient centrifugation with Lymphoprep (Lymphoprep 1.077, Nicomed Pharma AS, Oslo, Norway). The separated mononuclear cells were washed with isotonic phosphate buffered saline three times, and finally resuspended in the same solution.

Detection of apoptosis and necrosis. Apoptotic cells were detected using an Annexin V-FITC/7-AAD kit (Beckman Coulter IM3614). In the early phase of apoptosis, cell membrane integrity was maintained but the cells lost membrane phospholipid asymmetry. Phosphatidylserine (PS), a negatively charged phospholipid located in the inner leaflet of the plasma membrane, is then exposed at the cell surface. Annexin V, which is a calcium and phospholipid binding protein, binds preferentially to PS. In both late apoptosis and necrosis the cell membrane loses integrity and exposes DNA to viable dyes [27].

It is considered that Annexin $\mathrm{V}$ negative and 7-AAD negative cells are viable, Annexin $\mathrm{V}$ positive and 7-AAD negative cells are in the early stages of apoptosis, Annexin $V$ positive and 7-AAD positive cells are in late stages of apoptosis, while Annexin $\mathrm{V}$ negative and 7-AAD positive cells are necrotic. After isolation, cells were washed in PBS (p5493 Sigma-Aldrich) and re-suspended in ice cold binding buffer to the final concentration of 1 million cells $/ \mathrm{ml}$. Samples for analysis were prepared using $100 \mu \mathrm{l}$ of final solution incubated in the dark for 15 min with $10 \mu \mathrm{l}$ of AnnexinV-FITC and $20 \mu \mathrm{l}$ of 7-AAD and re-suspended in $400 \mu \mathrm{l}$ of ice cold binding buffer. Finally, cells were analyzed on an FC500 Beckman Coulter flow cytometer to the number of 20000 events, gating lymphocytes on the FS/SS diagram. The percentages of early and late apoptotic cells, as well as necrotic cells were determined using CXP Cytometer software.

Cytokinesis-block MN assay. Micronuclei were prepared using the Fenech and Morley method [28]. Whole heparinised blood $(0.5 \mathrm{ml})$ was added to $5 \mathrm{ml}$ of PBMax Karyotyping (Invitrogen, California, USA), the complete medium for lymphocyte culture. All cultures were incubated in duplicate at $37^{\circ} \mathrm{C}$ for $72 \mathrm{~h}$.

Forty-four hours after initiation of incubation, cytochalasin B (Sigma, St. Louis, MO, USA) was added at a final concentration of $4 \mu \mathrm{g} / \mathrm{ml}$. Cultures were harvested $28 \mathrm{~h}$ later. The cells were collected by centrifugation and re-suspended in a cold $\left(4^{\circ} \mathrm{C}\right)$ hypotonic solution $(0.56 \% \mathrm{KCl})$. The cells were then fixed in freshly prepared acetic acid-methanol $(1: 3 \mathrm{v} / \mathrm{v})$. The cell suspensions were dropped onto clean slides, air-dried and stained with $2 \%$ Giemsa for 12 min (Alfapanon, Novi Sad, Serbia). Scoring was performed using a light microscope (Nikon E50i) at $400 \mathrm{x}$ magnification following the criteria for MN scoring only in binucleated (BN) cells, as described by Fenech [29]. The MN frequencies were determined in 1000 BN lymphocytes from each patient.

Statistical analysis. All values were expressed as mean \pm standard deviation (SD). The commercial SPSS version 10.0 for Windows was used for statistical analysis. Student's t-test was employed for comparison of paired samples. For nonparametric variables, differences between two independent groups were determined by the Mann-Whitney U-test, while the Wilcoxon test was used for dependent groups. The observed variables were compared by the bivariate correlation test and Spearman coefficient. $P$ values less than 0.05 were considered to be statistically significant and those less than 0.01 highly significant.

\section{Results}

The study population consisted of 18 DTC patients and 18 control subjects. The clinical and pathological characteristics of the DTC patients are given in Table 1.

Table 2 presents the mean values of apoptosis/necrosis and micronuclei frequency in PBLs of the control subjects and the DTC patients before 131-I therapy. The mean value for early apoptosis of PBL in DTC patients before 131-I therapy was significantly higher than for the control subjects $(9.88 \pm$ $4.99 \%$ vs. $6.64 \pm 2.07 \%$; Mann Whitney test, $p=0.003$ ). The mean value for late apoptosis of PBLs in DTC patients before 131 -I therapy was $0.42 \pm 0.91 \%$ compared to $0.30 \pm 0.24 \%$ for the controls. The difference for late apoptosis between DTC patients before 131-I therapy and controls was not statistically significant. Moreover, there was no significant difference between the percentage of necrosis of PBLs in untreated DTC patients and controls $(0.11 \pm 0.32 \%$ vs. $0.025 \pm 0.04 \%)$. 
Table 1. Clinical and pathological characteristics of the patients with differentiated thyroid cancer

\begin{tabular}{lc}
\hline Characteristics & Patients (n) \\
\hline Sex & 12 \\
Female & 6 \\
Male & \\
Age (Yrs) & $38-76$ \\
$\quad$ Range & $50.5 \pm 11.5$ \\
Mean \pm SD & \\
Therapy doses (GBq) & 11 \\
3.7 & 7 \\
5.5 & \\
Tumor histology & 13 \\
P & 5 \\
P/F & \\
Tumor status & 12 \\
T1 & 5 \\
T2 & 1 \\
T3 & \\
Nodal status & 11 \\
N0 & 7 \\
N1 & \\
Metastasis distant & 17 \\
M0 & 1 \\
M1 &
\end{tabular}

${ }^{*}$ P-papillary carcinoma, P/F-papillary carcinoma with follicular infiltration (follicular subtype of papillary carcinoma)

Table 2. The mean values of apoptosis/necrosis and MN frequency in PBLs of control subjects and DTC patients before radioiodine therapy

\begin{tabular}{lrrc}
\hline & \multicolumn{1}{c}{ controls } & \multicolumn{1}{c}{ patients } & significance \\
\hline early apoptosis & $6.64 \pm 2.07$ & $9.88 \pm 4.99$ & $\mathrm{p}=0.003$ \\
late apoptosis & $0.30 \pm 0.24$ & $0.42 \pm 0.91$ & $\mathrm{p}=0.319$ \\
total apoptosis & $6.94 \pm 2.15$ & $10.30 \pm 5.38$ & $\mathrm{p}=0.004$ \\
necrosis & $0.025 \pm 0.04$ & $0.11 \pm 0.32$ & $\mathrm{p}=0.584$ \\
micronuclei & $4.66 \pm 2.42$ & $19.67 \pm 6.25$ & $\mathrm{p}<0.001$ \\
\hline
\end{tabular}

Table 3. The mean values of apoptosis/necrosis and MN frequency in PBLs of DTC patients before and after radioiodine therapy

\begin{tabular}{lrrr}
\hline & $\begin{array}{c}\text { patients } \\
\text { before 131-I }\end{array}$ & $\begin{array}{c}\text { patients } \\
\text { after 131-I }\end{array}$ & significance \\
\hline early apoptosis & $9.88 \pm 4.99$ & $13.53 \pm 6.57$ & $\mathrm{p}=0.008$ \\
late apoptosis & $0.42 \pm 0.91$ & $0.46 \pm 0.55$ & $\mathrm{p}=0.276$ \\
total apoptosis & $10.30 \pm 5.38$ & $13.99 \pm 6.61$ & $\mathrm{p}=0.008$ \\
necrosis & $0.11 \pm 0.32$ & $0.09 \pm 0.24$ & $\mathrm{p}=0.801$ \\
micronuclei & $19.67 \pm 6.25$ & $27.30 \pm 9.08$ & $\mathrm{p}<0.001$ \\
\hline
\end{tabular}

The mean MN frequency in the DTC patients before 131-I therapy was $19.67 \pm 6.25$, which was significantly higher than in PBLs of healthy controls ( $4.66 \pm 2.42$; Mann Whitney test, $\mathrm{p}<0.001)$. The mean values for apoptosis, necrosis and $\mathrm{MN}$ frequency in PBLs of DTC patients before and after therapy are given in Table 3. These were $9.88 \pm 4.99 \%$ and $13.53 \pm 6.57$
$\%$ respectively for early apoptosis of PBLs, and $0.42 \pm 0.91 \%$ and $0.46 \pm 0.55 \%$ respectively for late apoptosis. Cell necrosis before therapy was $0.11 \pm 0.32 \%$ and 7 days after therapy 0.09 $\pm 0.24 \%$. Applying the Wilcoxon test it was shown that the increase in early apoptosis after 131-I therapy was statistically significant $(\mathrm{p}=0.008)$. On the other hand, the differences before and after 131-I therapy for late apoptosis (Wilcoxon test, $p=0.276$ ) and necrosis (Wilcoxon test, $p=0.801$ ) of PBLs in DTC patients were not statistically significant.

The mean frequency of MN in the group of DTC patients after 131-I therapy was $27.30 \pm 9.08 / 1000 \mathrm{BN}$ cells, which was significantly higher than the values before therapy (19.67 \pm 6.25; paired-samples $\mathrm{T}$ test, $\mathrm{p}<0.001$ ).

There were no significant differences between $\mathrm{MN}$ frequencies before and after 131-I therapy in relation to both tumor stage (One Way ANOVA test, $\mathrm{p}_{\text {before }}=0.786, \mathrm{p}_{\text {after }}=0.722$ ) and the presence of metastases (Binary logistic regression, $\mathrm{p}_{\text {before }}=$ $\left.0.363, \mathrm{p}_{\text {after }}=0.716\right)$. Similarly, no significant differences in the frequencies of early and late apoptosis in relation to tumor stage (One Way ANOVA test, before 131-I therapy $\mathrm{p}_{\text {early }}=$ $0.978, \mathrm{p}_{\text {late }}=0.683$, and after 131-I therapy $\mathrm{p}_{\text {early }}=0.743$, $\mathrm{p}_{\text {late }}=$ 0.459 ) and the presence of metastases (Binar logistic regression, before therapy $\mathrm{p}_{\text {early }}=0.648, \mathrm{p}_{\text {late }}=0.337$, and after $\mathrm{p}_{\text {early }}$ $=0.743, \mathrm{p}_{\text {late }}=0.459$ ).

Figure 1 shows the early and late apoptotic events and necrosis of PBLs of two representative control subjects $(a, b)$ and two representative DTC patients, before $(c, e)$ and after 131-I therapy (d, f) using the annexin V-propidium iodide assay.

The results for MN frequency and level of apoptosis/ necrosis in PBLs of DTC patients and healthy controls are summarized in Table 4. DTC patients had higher levels of both early apoptosis and $\mathrm{MN}$ frequency than control subjects.

Statistical data indicated no significant difference in MN frequency before and after therapy in relation to patient gender (binary logistic regression, $\mathrm{p}_{\text {before }}=0.805, \mathrm{p}_{\text {after }}=0.940$ ), nor to dose of applied 131-I (binary logistic regression, $\mathrm{p}=$ 0.479 ).

Analysis of the relationships between two indicators of radiation-induced cell damage, apoptosis and $\mathrm{MN}$ frequency, showed a positive correlation between the values for MN frequency and early apoptosis before 131-I therapy (bivariate correlation test, Spearman $r=0.540, p=0.021$ ) and between $\mathrm{MN}$ frequency and total apoptosis before 131-I therapy (bivariate correlation test, Spearman $r=0.549, p=0.018$ ). In addition, we found a significant correlation between therapy-induced $\mathrm{MN}$ frequency (MN frequency after therapy reduced by MN frequency before therapy) and therapy induced early apoptosis (early apoptosis after therapy minus early apoptosis before therapy) (bivariate correlation test, Spearman $\mathrm{r}=0.585, \mathrm{p}=$ 0.014 ), as well as between therapy-induced $\mathrm{MN}$ frequency and therapy induced total apoptosis (total apoptosis after therapy minus total apoptosis before therapy) (bivariate correlation test, Spearman $\mathrm{r}=0.579, \mathrm{p}=0.015$ ). 
Control 1 .

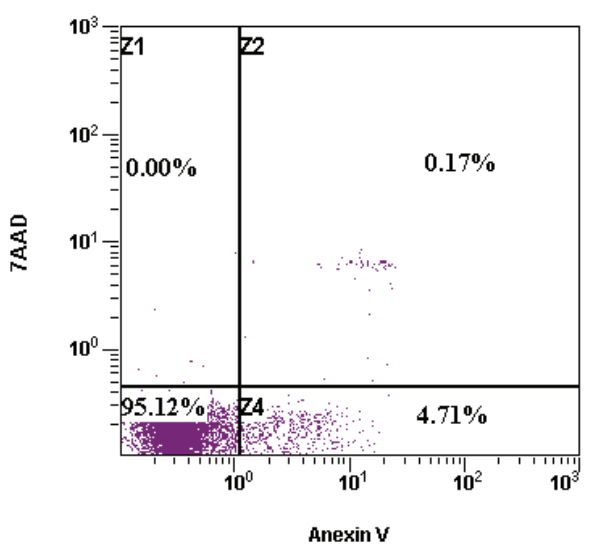

Patient 1.

Before therapy

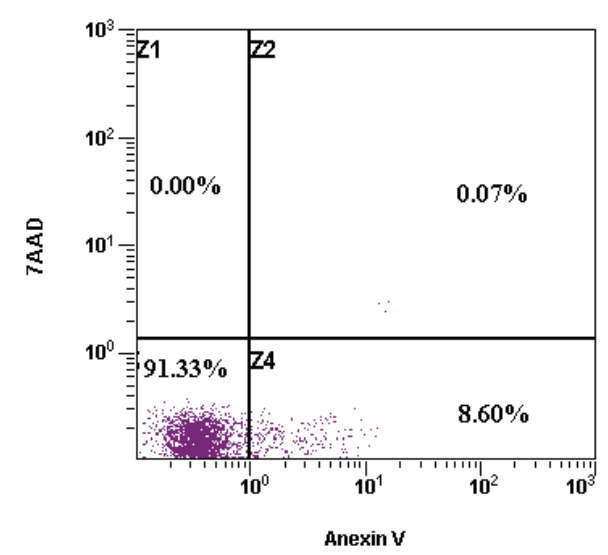

Patient 2.

Before therapy

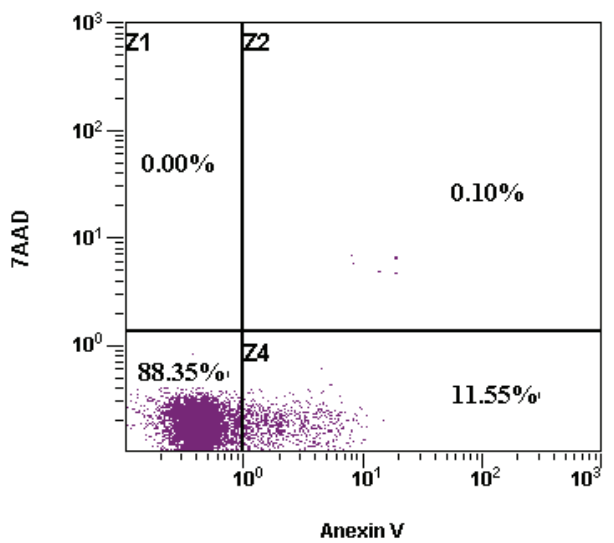

Control 2.

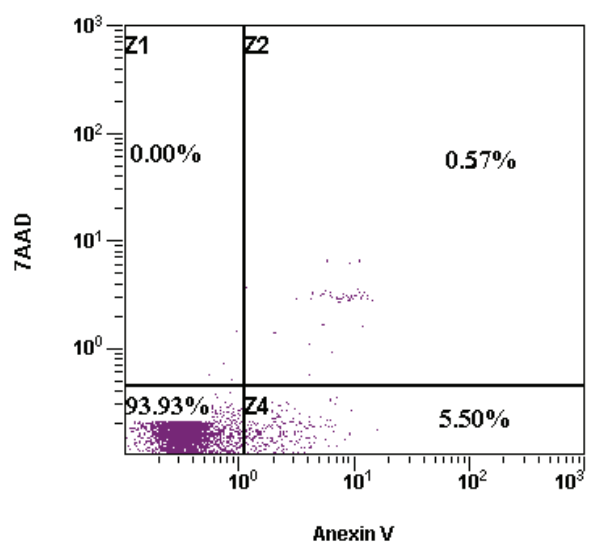

After therapy

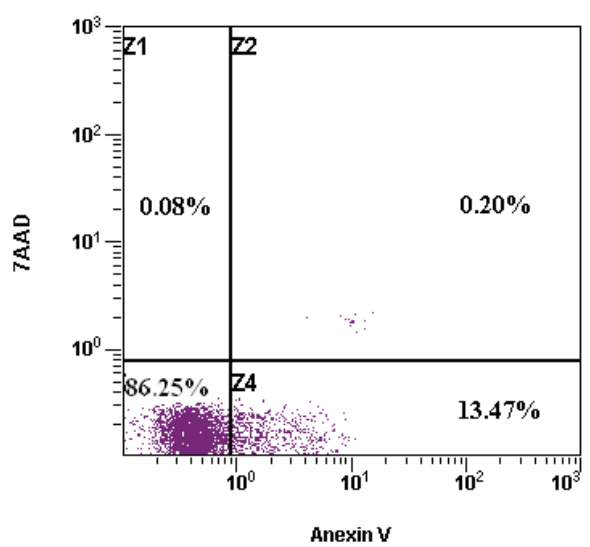

After therapy

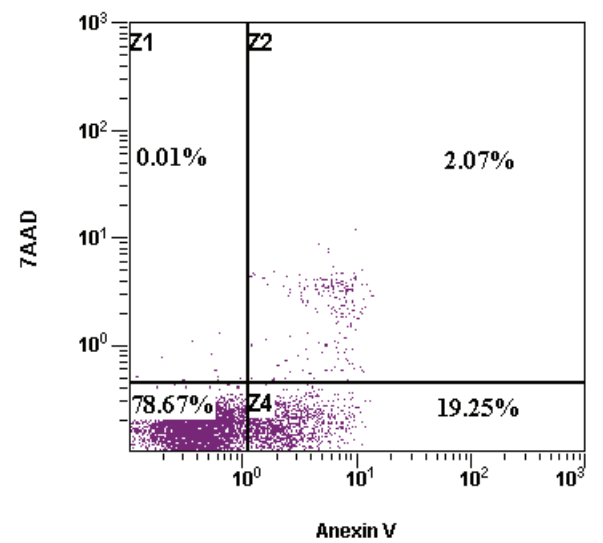

Figure 1. Apoptosis and necrosis in PBLs of two control subjects (a,b) and two DTC patients, before (c, e) and after radioiodine therapy (d, f) 
Table 4. Sumarized results of micronuclei frequency and apoptosis/necrosis level in PBL of DTC patients $(\mathrm{n}=18)$ and healthy controls $(\mathrm{n}=18)$

\begin{tabular}{|c|c|c|c|c|c|c|}
\hline \multirow[t]{2}{*}{ Analysis } & \multicolumn{4}{|c|}{ Patients } & \multicolumn{2}{|c|}{ Controls } \\
\hline & $\mathrm{n}$ & $\begin{array}{l}\text { before therapy } \\
\text { mean } \pm \mathrm{SD}\end{array}$ & & $\begin{array}{c}\text { after therapy } \\
\text { mean } \pm \text { SD }\end{array}$ & $\mathrm{n}$ & mean $\pm \mathrm{SD}$ \\
\hline Mean age (years) total & 18 & & $50.50 \pm 11.5$ & & 18 & $46.77 \pm 13.9$ \\
\hline Age range & & & $38-76$ & & & 30-79 \\
\hline \multicolumn{7}{|l|}{ MN frequency } \\
\hline total & & $19.67 \pm 6.25^{\mathrm{a}}$ & & $27.30 \pm 9.08^{b}$ & & $4.66 \pm 2.42$ \\
\hline \multicolumn{7}{|l|}{ Gender } \\
\hline Males & 6 & $19.16 \pm 7.35$ & & $27.50 \pm 11.41$ & 3 & $1.66 \pm 1.53$ \\
\hline Females & 12 & $19.92 \pm 5.97$ & & $27.16 \pm 8.25$ & 15 & $5.26 \pm 2.12$ \\
\hline \multicolumn{7}{|l|}{ Therapy doses (GBq) } \\
\hline 3.7 & 11 & $18.27 \pm 5.93$ & & $26.10 \pm 9.02$ & l & \\
\hline 5.5 & 7 & $21.86 \pm 6.56$ & & $29.14 \pm 9.54$ & l & \\
\hline Apoptosis (\%) & 18 & & & & 18 & \\
\hline Early & & $9.88 \pm 4.99^{c}$ & & $13.53 \pm 6.57^{\mathrm{d}}$ & & $6.64 \pm 2.07$ \\
\hline Late & & $0.42 \pm 0.91$ & & $0.46 \pm 0.55$ & & $0.30 \pm 0.24$ \\
\hline Necrosis (\%) & & $0.11 \pm 0.32$ & & $0.09 \pm 0.24$ & & $0.025 \pm 0.04$ \\
\hline
\end{tabular}

${ }^{a}$ statistically significant difference in mean MN frequency between patients and controls,

${ }^{b}$ statistically significant difference in mean MN frequency before and after therapy,

${ }^{c}$ statistically significant difference in early apoptosis between patients and controls,

d statistically significant difference in early apoptosis before and after therapy.

\section{Discussion}

In this study we investigated the effect of radioactive 131-I on apoptosis and MN frequency in PBLs of patients with DTC. Earlier work had shown that the PBLs of untreated patients with different types of tumors $[7,11,12]$ and papillary thyroid cancer [30] have an increased proportion of apoptotic cells. Our results are consistent with previously published data, but in comparison to patients with other types of tumors $[8,10]$, we obtained higher values of spontaneous apoptosis in PBLs before the applied therapy.

In order to estimate the total apoptosis of peripheral blood lymphocytes, we measured the percentage of PBLs in early stage of apoptosis (phosphatidylserine is expressed on the outer leaflet of cell membrane and the integrity of cell membrane is maintained) and late stage of apoptosis (phosphatidylserine is expressed on the outer leaflet of cell membrane, but the integrity of cell membrane is lost). The large differences in the percentage of cells in early and late stages of apoptosis obtained in our study could be explained by differences in duration of these stages of apoptosis. Namely, the duration of an apoptotic cell death has been estimated from a few hours to several days depending on the cell type $[1,2]$ and the initiator [31], while the late stage of apoptosis lasts about one hour [32, 33].

The mechanism responsible for apoptosis in PBLs of tumor patients is still a subject of research. One possible explanation for the high level of spontaneous apoptosis is intensification of the Fas (APO-1, CD95) / FasL pathway. Hoffman and colleagues [7] showed that a significant number of circulating lymphocytes in patients with head and neck cancer is eliminated through apoptosis, and that these cells are Fas-positive.
Also, it was found that cancer cells increasingly expressed functional FasL on their surface. The Fas/FasL pathway, including the presence of serum FasL, seems to play a key role in the survival and death of circulating lymphocytes. Besides that, there are other potential mechanisms responsible for enhanced apoptosis in PBLs of tumor patients, such as the presence of wild-type $\mathrm{p} 53$ gene, $\mathrm{c}$-myc induced cell death, overexpression of the pro-apoptotic molecules Bax or Bak, and the changes in cytokines production $[34,35]$.

The effect of radiotherapy on apoptosis in PBLs of patients with different types of tumors has been examined earlier [15, 16], but the influence of radioactive 131-I on apoptosis in PBLs of patients with DTC has not been studied so far. Our results show a significant increase of early apoptosis in PBLs of DTC patients treated with 131-I. Similar results were obtained by others $[36,37]$ as an effect of radiotherapy applied to patients with different types of tumors. It is assumed that radiotherapy leads to increased apoptosis in PBLs in two ways: by acting on the cell membrane and on the genetic material. The first mechanism involves degradation of membrane sphingomyelin by activation of sphingomyelinase and formation of ceramide, which promotes interphase death by apoptosis. On the other hand, radiation damages DNA, increasing p53-dependent transcription, and blocks the ubiquitin-dependent degradation of proteins, which also induces apoptosis [38].

Concerning the relationship between apoptosis and $\mathrm{MN}$, we found a positive correlation between $\mathrm{MN}$ frequency and early apoptosis in PBLs before therapy, as well as between iodine 131-induced MN frequency and iodine 131-induced early apoptosis in PBLs of DTC patients. Considerable individual variation has been found for radiation induced apoptosis 
and $\mathrm{MN}$ frequency $[39,40]$, as occurred in our DTC patients treated with 131-I.

Apoptosis is the physiological response of cells to the action of different harmful agents, including exposure to radiation. This active process is accompanied by chromatin condensation and could contribute to the formation of micronuclei, which segregate inactive genetic material $[39,41]$. Apoptosis and micronuclei occur after the first mitosis and therefore reflect damage to genetic material. The relationship between radiation therapy-induced apoptosis and micronuclei frequency was analyzed previously $[42,43]$. In several studies the incidence of apoptosis was found to correlate negatively with $\mathrm{MN}$ frequency $[44,45,46]$, while in others apoptosis correlated positively with MN frequency [47]. Using a chemical agent, Decordier and coworkers showed that the frequency of cells with MN was higher in the apoptotic cell fraction and concluded that the formation of MN in cells correlates with apoptosis and therefore contributes to the elimination of damaged cells [48]. Moreover, they suggested that $\mathrm{MN}$ could be a signal for apoptosis, whereby $\mathrm{MN}$ formation is related to the early stages of apoptosis.

Meintieres et al. [49] detected an increase of MN frequency in cells with overexpression of the antiapoptotic protein, $\mathrm{Bcl}-2$, suggesting that inhibition of apoptosis may allow cells with a significant level of DNA damage to continue the cell cycle and to survive as MN-bearing cells. In contrast, increased apoptotic capacity may lead to the elimination of cells with MN and therefore to reduction in the total number of MN. Thus, $\mathrm{MN}$ frequency, as a marker of DNA damage, might depend on whether the damaging agent acts as a promoter or inhibitor of apoptosis [50], but the effects of other factors that regulate apoptotic events may also be involved. In this study, it was shown that radioactive 131-I induces an increase in apoptosis and $\mathrm{MN}$ frequency, with a positive correlation between them. This could indicate that, despite enhanced apoptosis, the intensity is not sufficient to remove the increased number of cells with MN. A better understanding of the relationship between $\mathrm{MN}$ formation and apoptosis requires analysis of micronuclei origin, but that was not the subject of our investigation.

In conclusion, patients with DTC have a significantly higher level of early apoptosis in PBLs than healthy subjects, which additionally increases after 131-I therapy. Radioactive iodineinduced early apoptosis in PBLs of DTC patients was positively associated with MN frequency.

Acknowledgements: The study was supported by the Ministry of Education, Science and Technological Development of the Republic of Serbia (Grant nos. III41010 and ON175069).

\section{References}

[1] KERR JFR, WYLLIE AH, CURRIE AR. Apoptosis: A basic biological phenomenon with wide-ranging implications in tissue kinetics. Br J Cancer 1972; 26: 239-257. http://dx.doi. org/10.1038/bjc.1972.33
[2] SARASTE A, PULKKI K. Morphologic and biochemical hallmarks of apoptosis. Cardiovasc Res 2000; 45: 528-537. http://dx.doi.org/10.1016/S0008-6363(99)00384-3

[3] FADOK VA, DE CATHELINEAU A, DALEKE DL, HENSON PM, BRATTON DL. The loss of phospholipid asymmetry and surface exposure of phosphatidylserine is required for phagocytosis of apoptotic cells by macrophages and fibroblasts. J Biol Chem 2001; 276: 1071-7. http://dx.doi.org/10.1074/jbc. $\underline{\mathrm{M} 003649200}$

[4] ELMORE S. Apoptosis: A review of programmed cell death. Toxicol Pathol 2007; 35: 495-516 http://dx.doi.org/10.1080/ 01926230701320337

[5] VERMES I, HAANEN C, REUTELINGSPERGER C. Flow cytometry of apoptotic cell death. J Immunol Methods 2000; 243: 167-190. http://dx.doi.org/10.1016/S0022-1759(00)00233-7

[6] RASTOGI RP, RICHA, SINHA RP. Apoptosis: Molecular mechanisms and pathogenicity. EXCLI Journal 2009; 8: 155-181.

[7] HOFFMANN TK, DWORACKI G, TSUKIHIRO T, MEIDENBAUER N, GOODING W. et al. Spontaneous apoptosis of circulating $\mathrm{T}$ lymphocytes in patients with head and neck cancer and its clinical importance. Clin Cancer Res 2002; 8: 2553-2562.

[8] MUNEAKI S, TACHIBANA M, DHAR DK, OHNO S, KUBOTA H. et al. Spontaneous apoptosis in advanced esophageal carcinoma: its relation to Fas expression. Clin Cancer Res 2000; 6: 4755-4759.

[9] KUPRYJANCZYK J, DANSONKA-MIESZKOWSKA A, SZYMANSKA T, KARPINSKA G, REMBISZEWSKA A. et al. Spontaneous apoptosis in ovarian carcinomas: a positive association with p53gene mutation is dependent on growth fraction. Br J Cancer 2000; 82: 579-583.

[10] MANDOKY L, SZENDE B, GECZI L, BODROGI I, KASLER M. et al. Apoptosis regulation and spontaneous apoptosis index of testicular germ cell tumors are associated with differentiation and resistance to systemic treatment. Anticancer Res 2008; 28: 1641-1649.

[11] PINZON-CHARRY A, MAXWELL T, MCGUCKIN MA, SCHMIDT C, FURNIVAL C. et al. Spontaneous apoptosis of blood dendritic cells in patients with breast cancer. Breast Cancer Res 2006; 8: R5. http://dx.doi.org/10.1186/ bcr1361

[12] SAITO T, DWORACKI G, GOODING W, LOTZE MT, AND WHITESIDE TL. Spontaneous apoptosis of CD8+ T lymphocytes in peripheral blood of patients with advanced melanoma. Clin Cancer Res 2000; 6: 1351-1364.

[13] XU JL, LAI R, KINOSHITA T, NAKASHIMA N, AND NAGASAKA T. Proliferation, apoptosis, and intratumoral vascularity in multiple myeloma: correlation with the clinical stage and cytological grade. J Clin Pathol 2002; 55: 530-534. http://dx.doi.org/10.1136/jcp.55.7.530

[14] FERREIRA CG, EPPING M, KRUYT FAE, AND GIACCONE G. Apoptosis: target of cancer therapy. Clin Cancer Res 2002; 8: 2024-2034.

[15] BORDON E, HERNANDEZ LA, LARA PC, PINAR B, FONTES F. et al. Prediction of clinical toxicity in localized cervical carcinoma by radio-induced apoptosis study in peripheral 
blood lymphocytes (PBLs). Radiat Oncol 2009; 4: 58-64. http://dx.doi.org/10.1186/1748-717X-4-58

[16] PINAR B, HENRIQUEZ-HERNANDEZ LA, LARA PC, BORDON E, RODRIGUEZ-GALLEGO C. et al. Radiation induced apoptosis and initial DNA damage are inversely related in locally advanced breast cancer patients. Radiat Oncol 2010; 5: 85-89. http://dx.doi.org/10.1186/1748-717X-5-85

[17] FENECH M, KIRSCH-VOLDERS M, NATARAJAN AT, SURRALLES J, CROTT JW. et al. Molecular mechanisms of micronucleus, nucleoplasmic bridge and nuclear bud formation in mammalian and human cells. Mutagenesis 2011; 26: 125-132. http://dx.doi.org/10.1093/mutage/geq052

[18] NORPPA H, BONASSI S, HANSTEEN IL, HAGMAR L, STROMBERG U. et al. Chromosomal aberrations and SCEs as biomarkers of cancer risk. Mutat Res 2006; 600: 37-45. http://dx.doi.org/10.1016/j.mrfmmm.2006.05.030

[19] BONASSI S, ZNAOR A, CEPPI M, LANDO C, CHANG WP, et al. An increased micronucleus frequency in peripheral blood lymphocytes predicts the risk of cancer in humans. Carcinogenesis 2006; 28: 625-631. http://dx.doi.org/10.1093/ carcin/bgl177

[20] MURGIA E, BALLARDIN M, BONASSI S, ROSSI AM, AND BARALE R. Validation of micronuclei frequency in peripheral blood lymphocytes as early cancer risk biomarker in a nested case-control study. Mutat Res 2008; 639: 27-34. http://dx.doi. org/10.1016/j.mrfmmm.2007.10.010

[21] LEE TK, ALLISON RR, O'BRIEN KF, NAVES JL, KARLSSON UL. et al. Persistence of micronuclei in lymphocytes of cancer patients after radiotherapy. Radiat Res 2002; 157: 678-684. http://dx.doi.org/10.1667/0033-7587(2002)157[0678: POMILO]2.0.CO;2

[22] IARMARCOVAI G, CEPPI M, BOTTA A, ORSIERE T, and BONASSI S. Micronuclei frequency in peripheral blood lymphocytes of cancer patients: A meta-analysis. Mutat Res 2008; 659: 274-283. http://dx.doi.org/10.1016/ j.mrrev.2008.05.006

[23] WATANABE N, YOKOYAMA K, KINUYA S, SHUKE N, SHIMIZU M, et al. Radiotoxicity after iodine-131 therapy for thyroid cancer using the micronucleus assay. J Nucl Med 1998; 39: 436-440.

[24] BALLARDIN M, GEMIGNANI F, BODEI L, MARIANI G, FERDEGHINI M. et al. Formation of micronuclei and of clastogenic factor(s) in patients receiving therapeutic doses of iodine-131. Mutat Res 2002; 514: 77-85. http://dx.doi. org/10.1016/S1383-5718(01)00323-0

[25] JOSEPH LJ, BHARTIYA US, RAUT YS, KAND P, HAWALDAR RW, et al. Micronuclei frequency in peripheral blood lymphocytes of thyroid cancer patients after radioiodine therapy and its relationship with metastasis. Mutat Res 2009; 675: 35-40. http://dx.doi.org/10.1016/ j.mrgentox.2009.02.004

[26] LUSTER M, CLARKE SE, DIETLEIN M, LASSMANN M, LIND P. et al. Guidelines for radioiodine therapy of differentiated thyroid cancer. Eur J Nucl Med Mol Imaging 2008; 35: 1941-1959. http://dx.doi.org/10.1007/s00259-008-0883-1

[27] SHOUNAN Y, FENG X, AND O`CONNELL PJ. Apoptosis detection by annexin $\mathrm{V}$ binding: a novel method for the quantitation of cell-mediated cytotoxicity. J Immunol Methods 1998; 217: 61-70. http://dx.doi.org/10.1016/S00221759(98)00090-8

[28] FENECH M AND MORLEY AA. Measurement of micronuclei in lymphocytes. Mutat Res 1985; 147: 29-36. http://dx.doi.org/10.1016/0165-1161(85)90015-9

[29] FENECH M. The in vitro micronucleus assay. Mutat Res 2000; 455: 81-95. http://dx.doi.org/10.1016/S0027-5107(00)00065$\underline{8}$

[30] MARDENTE S, LENTI L, LOCOCO E, CONSORTI F, DELLA ROCCA C. et al. Phenotypic and functional characterization of lymphocytes in autoimmune thyroiditis and in papillary carcinoma. Anticancer Res 2005; 25: 2483-2488.

[31] WILLINGHAM MC. Cytochemical methods for the detection of apoptosis. The Journal of Histochemistry \& Cytochemistry 1999, 47(9): 1101-1109. http://dx.doi. org/10.1177/002215549904700901

[32] BURSCH W, PAFFEL S, PUTZ B, BARTHEL G, and SCHULTE-HERMANN R. Determination of the length of the histological stages of apoptosis in normal liver and in altered hepatic foci of rats. Carcinogenesis 1990; 11(5): 847-853. http://dx.doi.org/10.1093/carcin/11.5.847

[33] MILLS JC, STONE NL, and PITTMAN RN. Extranuclear apoptosis: The role of the cytoplasm in the execution phase. J Cell Biol 1999; 146: 703-708. http://dx.doi.org/10.1083/ jcb.146.4.703

[34] LOWEL SW AND LIN AW. Apoptosis in cancer. Carcinogenesis 1999; 21: 485-495.

[35] DJURDJEVIC P, ZELEN I, RISTIC P, BASKIC D, POPOVIC S. et al. Role of Decreased Production of Interleukin-10 and Interferon-Gamma in Spontaneous Apoptosis of B-Chronic Lymphocytic Leukemia Lymphocytes In Vitro. Archives of Medical Research 2009; 40(5): 357-363. http://dx.doi. org/10.1016/j.arcmed.2009.05.007

[36] OZSAHIN M, CROMPTON N, GOURGOU S, KRAMAR A, LI L. et al. CD4 and CD8 T-Lymphocyte apoptosis can predict radiation-induced late toxicity: A prospective study in 399 patients. Clin Cancer Res 2005; 11: 7426-7433. http://dx.doi. org/10.1158/1078-0432.CCR-04-2634

[37] TORUDD J, PROTOPOPOVA M, SARIMOV R, NYGREN J, ERIKSSON S. et al. Dose - response for radiation-induced apoptosis, residual 53BP1 foci and DNA-loop relaxation in human lymphocytes. Int J Radiat Biol 2005; 81: 125-138. http://dx.doi.org/10.1080/09553000500077211

[38] ROSS GM. Induction of cell death by radiotherapy. Endocrine-Related Cancer 1999; 6: 41-44. http://dx.doi. org/10.1677/erc.0.0060041

[39] CROMPTON NEA, SHI Y, EMERY GC, WISSER L, BLATTMANN H. et al. Sources of variation in patient response to radiation treatment. Int J Radiat Oncol Biol Phys 2001; 49: 547-554. http://dx.doi.org/10.1016/S0360-3016(00)01477-2

[40] VRAL A, THIERENS H, BAEYENS A. and DE RIDDER L. Chromosomal aberrations and in vitro radiosensitivity: intra-individual versus inter-individual variability. Toxicol Letters 2004; 149: 345-352. http://dx.doi.org/10.1016/ j.toxlet.2003.12.044 
[41] SOLOMON WL, MEEHAN KA, GIHWALA D, AND SLABBERT JP. Leukocyte apoptosis and micronuclei induction in individuals with varying sensitivity to ionizing radiation. Medical Technol SA 2010; 24: 29-32.

[42] GUO GZ, SASAI K, OYA N, TAKAGI T, SHIBUYA K, et al. Simultaneous evaluation of radiation-induced apoptosis and micronuclei in five cell lines. Int J Radiat Biol 1998; 73: 297-302. http://dx.doi.org/10.1080/095530098142392

[43] BELYAKOV OV, PRISE KM, TROTT KR AND MICHAEL BD. Delayed lethality, apoptosis and micronuclei formation in human fibroblast irradiated with X-rays or a-particles. Int J Radiat Biol 1999; 75: 985-993. http://dx.doi.org/10.1080/ $\underline{095530099139746}$

[44] LIU ZZ, HUANG WY, LI XS, LIN JS, CAI XK, et al. Prediction value of radiosensitivity of hepatocarcinoma cells for apoptosis and micronucleus assay. World J Gastroenterol 2005; 11 : 7036-7039.

[45] TAGHAVI-DEHAGHANI M, MOHAMMADI C, ZIAFAZELI T, AND SARDARI-KERMANI M. A Study on Differences between radiation-induced micronuclei and apoptosis of lymphocytes in breast cancer patients after radiotherapy. Z Naturforsch 2005; 60c: 938-942.

[46] UTANI K, KOHNO Y, OKAMOTO A, and SHIMIZU N. Emergence of micronuclei and their effects on the fate of cells under replication stress. PLoS ONE 2010; 5: e10089. http://dx.doi.org/10.1371/journal.pone.0010089

[47] SIMKO M, KRIEHUBER R, WEISS DG, AND LUBEN RA. Effects of $50 \mathrm{~Hz}$ EMF exposure on micronucleus formation and apoptosis in transformed and non transformed human cell line. Bioelectromagnetics 1998; 19: 85-91. http:// dx.doi.org/10.1002/(SICI)1521-186X(1998)19:2<85::AIDBEM5>3.0.CO;2-\#

[48] DECORDIER I, DILLEN L, CUNDARI E, and KIRSCHVOLDERS M. Elimination of micronucleated cells by apoptosis after treatment with inhibitors of microtubules. Mutagen 2002; 17: 337-344. http://dx.doi.org/10.1093/ mutage/17.4.337

[49] MEINTIERES S, BIOLA A, PALLARDYM M, and MARZIN D. Using CTLL-2 and CTLL-2 bcl2 cells to avoid interference by apoptosis in the in vitro micronucleus test. Environ Mol Mutagen 2003; 41: 14-27. http://dx.doi.org/10.1002/ em.10126

[50] FENECH M, CROTT J, TURNER J, and BROW S. Necrosis, apoptosis, cytostasis and DNA damage in human lymphocytes measured simultaneously within the cytokinesis-block micronucleus assay: description of the method and results for hydrogen peroxide. Mutagenesis 1999; 14: 605-612. http:// dx.doi.org/10.1093/mutage/14.6.605 